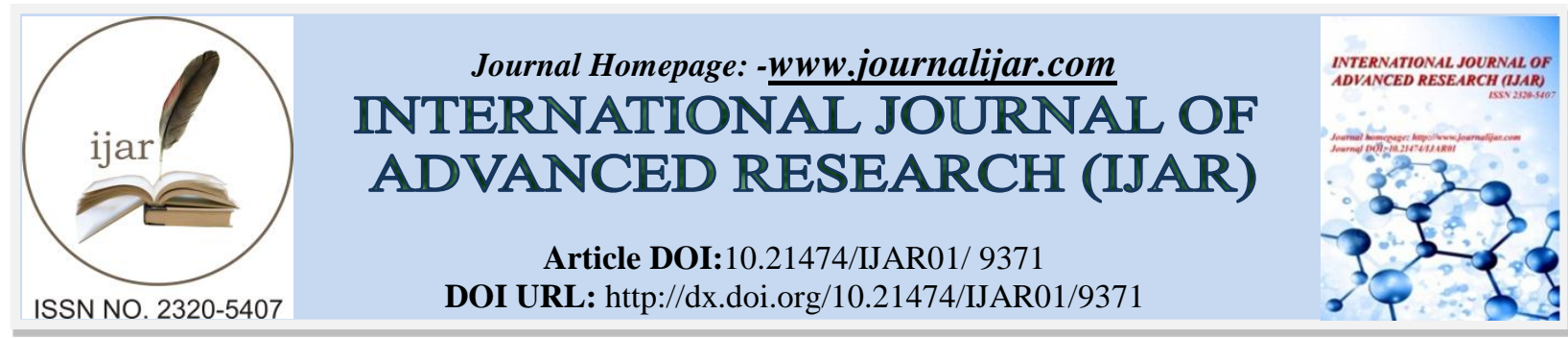

RESEARCH ARTICLE

\title{
EXPECTATIONS AND CHALLENGES OF IMPLEMENTATION INCLUSIVE EDUCATION PROGRAM: A CASE STUDY.
}

Hamsi M. ${ }^{1}$, Mohd Hanafi M.Y. ${ }^{2}$ and Liong, K.T. ${ }^{2}$.

1. Lambung Mangkurat University (ULM), Banjarmasin, Kalimantan Selatan, Indonesia.

2. Faculty of Education, National University of Malaysia.

\section{Manuscript Info}

Manuscript History

Received: 10 May 2019

Final Accepted: 12 June 2019

Published: July 2019

Key words:-

Educational program, Inclusive,

Countenance evaluation.

\section{Abstract}

This research aims to find out the effectiveness of the implementation of inclusive education programs at the level of middle-high school (SMP) in Banjarmasin, South Kalimantan Province of Indonesia. Qualitative approach was used by applied countenance evaluation model to investigate in what extent of the inclusive education programs have been implemented. The main data of this study consisted of: (a) the component of preparation (antecedents) of the implementation of inclusive education programs evaluation, (b) the component of process (transactions) of the implementation of inclusive education programs evaluation, and (c) the component of products (outcomes) of the implementation of inclusive education programs evaluation at the level of middle-high (SMP) school in Banjarmasin. The subjects of this research were consisted of headmaster, teachers of field study, supervising teachers, school committee, and students' parents of inclusive education program. The results showed that (a) the component of the preparation (antecedents) had not planned well, (b) the component of process (transaction) did not been running effectively, and (c) the component of products (outcomes) as well as the results of the implementation of inclusive education were not been maximized. Thus, some further actions are needed to be taken by stakeholders and parents in enhancing the effectiveness of implementation of inclusive education programs.

Copy Right, IJAR, 2019,. All rights reserved.

\section{Introduction:-}

One of the government policies in addressing equalization of education is provided inclusive education programs in schools. An inclusive program is a service served for those children with special needs in obtaining decent education (Kemendikbud, 2003). The government policy is stated in Law of Art No. 20 year 2003 Statement 23 and Permendiknas No. 70 year 2009. The Act provides the opportunities for students with special needs to obtain education in regular schools. Inclusive education program can facilitates students with special needs to study together with normal students. The program also enable students with special needs to be treated like normal students. From the psychological view, inclusive program shows positive impacts for students with special needs. As it is proposed by Sukinah (2010:40), inclusive education is an implementation of multicultural education which

Corresponding Author:-Hamsi M.

Address:-Lambung Mangkurat University (ULM), Banjarmasin, Kalimantan Selatan, Indonesia. 
can help learners understand, accept, and appreciate each other of different tribes, culture, values, personality, and physical and psychological disorder.

The presence of inclusive school is an effort for the alleviation nine years compulsory education. So far, students with special needs cannot completed nine years education because they live far away from disabilities and special needs schools (SLB). In addition, some students are from poor family backgrounds. As a result, theirs' parents can't afford to serve them to attend formal education in school. In Indonesia, SLB is generally located in the capital cities of the district. In fact, students with special needs are spread throughout the area included sub-district and village, not only in the capital city of the district. However, students can't attend to school due to poor family backgrounds with low income and the distance of the school is too far. They aren't afford to pay accommodation and transportation expenses. On the other hand, if they study in nearby elementary schools, they will encounter an obstacle in learning due to the limitations of special teachers. As a consequence, students' schools attending could be potentially descrease and eventually dropped out of school. These problems may result in failure of the nine years compulsory education program (Direktorat PLB, 2007:2).

Inclusive education policy in Indonesia has started approximately for night years, including the organizing of inclusive education in the City of Banjarmasin in South Kalimantan. However, the implementation of inclusive education faced some problems in few cities of Indonesia such as Bandung, Sidoarjo, and Central Java. In B andung and Sidoarjo for instance, some problems that could not be accommodated by the school were found such as the curriculum which has not been modified to fit students with special needs, the lack of accessibility for special needs learners, as well as the lack of attention and awareness of regular school teachers to the students with special needs (Ummah, 2011:1).

A study was carried out by Haryono, Ahmad Syaifudin, and Rogram (2015:125) in Central Java revealed that was inefficient students management of inclusive education program in province of Central Java. This is due to the process of admission in which there is no limit or quota for the students with special needs, the process of identification and assessment was not carried out, and the forms or sheets of identification and assessment were not available in each inclusive education program at school. In addition, the inclusive education curriculum management in province of Central Java was not applied consistently in which the curriculum was developed based on a modified model of instructional documents that consisted of three elemens as syllabus, lesson plan, and evaluation system. The inconsistencies of inclusive education curriculum management were included the Individual Learning Program (PPI) was not given to students with special needs and the assessment report for learning process was not designed based on the learning purposes. The same condition was also found on the teacher management in inclusive schools of Central Java province. It was caused by the failure of the teachers to comprehend the implementation of inclusive education in regular schools. For this reason, teachers still need training on inclusive education program (Pratiwi, 2015: 237).

Such conditions in fact is not much different from that which is occurring in the city of Banjarmasin, South Kalimantan. The observation and initial research on the implementation of inclusive education in Banjarmasin showed that teachers were confused with individual learning service for students with special needs, special teachers were insufficient, teachers' awareness of inclusive education were less, and teachers as well as the headmasters were lack of knowledge of the procedures in organizing inclusive education (Rahim \& Mansur, 2013: 1). None of the inclusive education program providers from Junior High School could accept students with special needs because the school did not have special teacher. These findings were certainly not in line with the philosophy of inclusive education.

Based on the aforementioned data, the implementation of inclusive education in Banjarmasin needs to be evaluated systematically for the sake of accomplishing the goals of inclusive education. The evaluation process is expected to be beneficial for the development of inclusive education programs. Evaluation is seen as a process which can determine the outcome of the planned activities to support the achievement of certain objectives (Don E. Gardner, 1977). The evaluation on the implementation of inclusive education program will explore the extent to which the objectives of the program are implemented. Furthermore, the results can be used to determine an appropriate alternative in making decisions of inclusive education program implementation.

The purpose of this research is to identify in what extent of the effectiveness of implementation inclusive education program requires the evaluation with regard to the various standard criteria in implementing inclusive education 
(Arikunto, 2008). Therefore, the appropriate method and evaluation model are needed in accordance with the research objectives. Among the models of evaluation, Countenance Evaluation Model is considered in accordance with objectives of this research. This model emphasizes on the evaluation aspects of implementation which consists of preparation, process, and outcomes of a program, as well as other criteria and expectations of the people involved in inclusive education programs (Tayibnapis and Farida Yusuf, 2008).

\section{Material and Methods:-}

The method used in this research was the qualitative approach to uncover the facts, circumstances, phenomenon, variable, and circumstances that occurred during the research conducted and presented data (Miles, Mattew B. and A. Michael Huberman, 1992). The evaluation method applied in this study was the Model of Evaluation Countenance for two reasons. First, countenance model provides much information from all phases of the evaluation. Second, the countenance model gives more detailed information on each stage of the evaluation of the standards used (Stake, R.E., 1983). This research subjects are all of the stakeholders with regard to the implementation of inclusive education in Junior High Schools in Banjarmasin, that included headmaster, teachers of field study, supervising teachers, school committee, and students' parents of inclusive education program. The objective of the research is the implementation of inclusive education programs in Junior High School 10 in Banjarmasin.

The data analysis was carried out qualitatively by describing each of the data under evaluation. The analysis was consistent since the beginning of the data collection, which consisted of three interrelated phases, namely the reduction of data, data presentation, and conclusion. The process of data analysis was conducted from the beginning of the process until the end of the initial data collection. The data were collected through interviews, observations, and analysis of documents which were then reduced by means of selecting, determining the focus, and simplifying it. The model of countenance was depicted in Figure 1 as below.

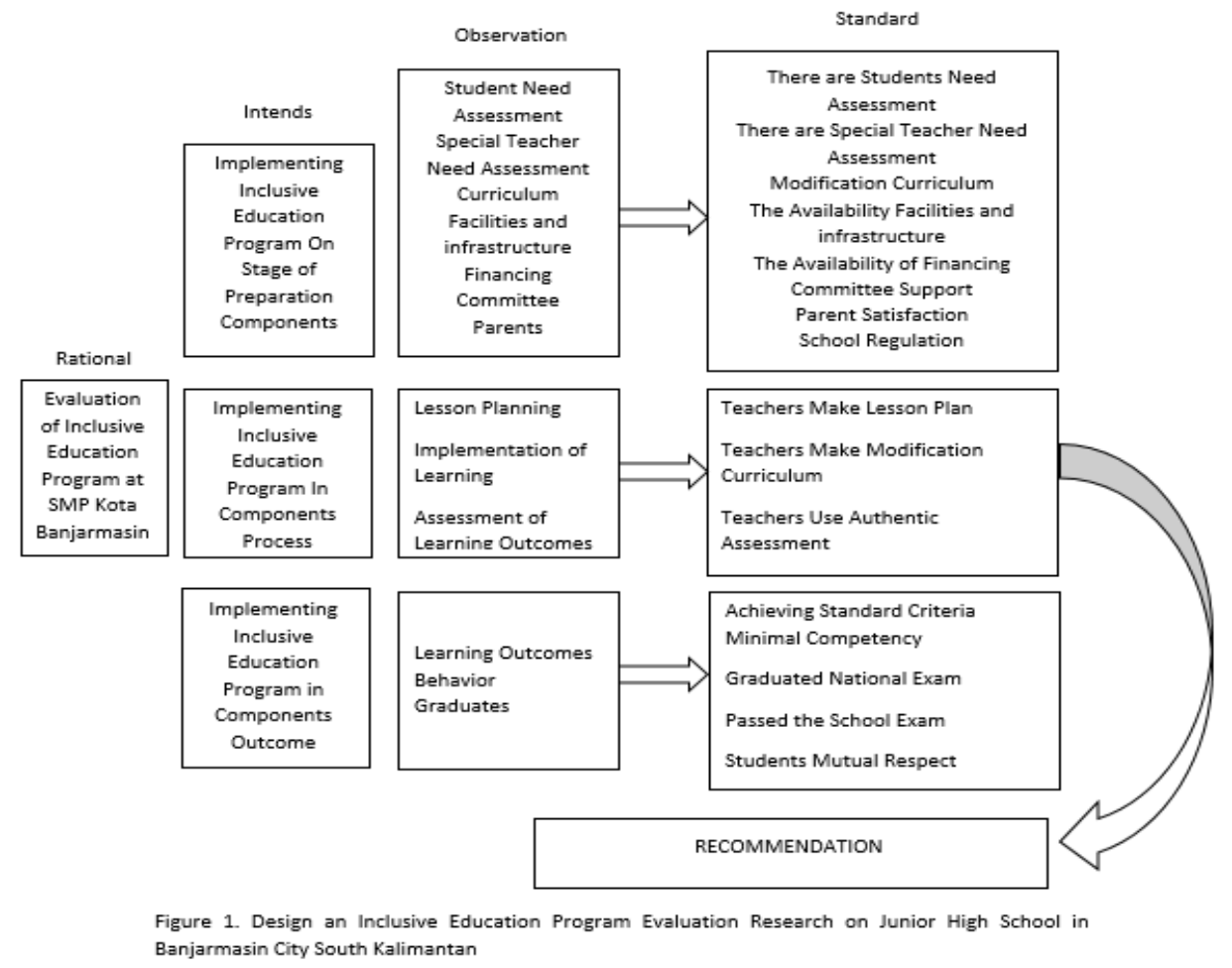

\section{Result and Discussion:- \\ Result}

The discussions on the findings of the study will cover the overall results, analysis, and interpretation of the results. The data obtained was qualitative data therefore its analysis was carried out qualitatively as follows: 


\begin{abstract}
Antecedent
The first component was input (antecedent) which consisted of a recruitment of students with special needs, identification and assessment, special teacher recruitment, curriculum, facilities and infrastructure, financing, school committee or student's parents, satisfaction of users, the making of school rules about the standard of organizing and managing the inclusive school, the professionalism of the inclusive school teachers by providing education and training as well as awards for those teachers have teaching hours exceed the specified limit. From all components, it was found that the implementation of inclusive education programs in SMP 10 Banjarmasin was not quite effective based on the standard criteria. There were many aspects of the component of the antecedent that had not been fulfilled in implementing inclusive education in the school.
\end{abstract}

\title{
Transaction
}

The second was the scope of transactions relating to the ability of teachers in planning the learning activities for students with special needs and carrying out an assessment on the students' learning. From this component, there were many aspects which were not suit the standard evaluation criteria such as: (a) teachers had not yet compiled the lesson plans (RPP) corresponding to the characteristics of students with special needs (ABK), (b) special teachers had designed the individual learning program (IPP), (c) teachers had not modified the curriculum to suit their students' needs, and (d) there did not have any scoring system which had been designed to evaluate the students' ability.

\section{Outcomes}

The third component was the outcomes namely: (a) the results of students' learning which consisted of scores ranking in class and book reports, (b) social behaviors, and (c) the final National Examination (UN) as well as the schools examination. Referring to the data of inclusive education program in the city of Banjarmasin, it can be concluded that there were some aspects which had met the standard evaluation criteria, but there was also another aspect that was still not in accordance with standard evaluation criteria. The aspects which had met the standard were the students' behavior which showed mutually appreciated each other and the fact that students could pass the school examination as well as the National Examination. Meanwhile, the aspect which did not meet the standards of minimum criteria of learning (KKM) was the students' scores.

\section{Matrix Description}

There were components of the antecedent showed the relevance between the purpose and the results of the observation. However, there were some components which did not meet the standards of the evaluation criteria. There were recruitment of students and teachers, assessment service, modifications of the curriculum, facilities, rewards for teachers those teaching hours exceed the maximum limit, school rules about the standard of inclusive education management, and parental satisfaction. The components of data transactions did not meet the overall evaluation criteria standard. The data analysis indicated that teachers' skills in planning the lesson, teachers' ability in teaching and conducting an assessment of learning among the students with special needs (ABK) were still not fulfilled the expected competencies. The component outcomes, however, were slightly different from the previous components. Within this component there were a couple of things which were in accordance with the standard criteria. Nevertheless, the aspect of the minimum criteria of learning (KKM) still did not meet the standards. It can be concluded that this component has not been implemented appropriately to its full potential.

\section{Decision Matrix}

Based on aforementioned matrix description, the schools need to improve several components and aspects of inclusive education management, and to convene it in both schools (which ran for 7 years) so that inclusive education can be run more effectively. It is expected that conducting inclusive education in both schools can manifest the construction of the five pillars of education, namely improving availability of education services, increasing the affordability of education services, improving the quality and relevance of education services, increasing equality in obtaining education services, and enhancing or acquiring secure services of education.

\section{Discussion:-}

\section{Antecedent}

On the aspect of antecedent (prior to implementation) there are several aspects that have been carried out in accordance with the guidelines of the inclusive education. Nonetheless, there are still several aspects which have not been done properly in accordance with the instructions of the implementation guidelines. First, the recruitment of prospective students. The findings of this study showed that Junior High School 10 of Banjarmasin had granted 
quota for admitting prospective students. It means that school has provided the opportunity to prospective students to continue learning in inclusive education. It corresponds to the Permendiknas No. 70 year 2009 related to inclusive education for students with special needs and those with exceptional talent on pasal 2. Despite giving quota to students with special needs, the school admission process has not implemented the assessment service.

Second, the availability of Special Teachers (GPK). So far, local government does not give insufficient attention to GPK recruitment in schools as inclusive education providers at junior level. In school setting of current study, GPK are not available because the agreement on waging system has not been made by both school and parents. If the school with limited funding was asked to recruit GPK without any financial assist by government, it ascertained that GPK won't be paid. To resolve this issue, the school over-handed the management of the students to the counselling teachers $(\mathrm{BK})$. By the way, BK teachers can provide counselling guidance and service to students with special needs. Unfortunately, this can be difficult to be implemented properly. The implementation of guidance, learning, and educational programs can only be conducted properly when it is run by experts, i.e. the graduates of the major study of PLB. It is delivered as Delphi (Patton, 2009: 52) the most important is that the teachers have qualification as undergraduate degree in PLB because they know and understand about the appropriate services for students with special needs of inclusive programs, both in terms of academic as well as non-academic.

Third, the curriculum modifications in Junior High School 10 of Banjarmasin are categorized as good. According to the researchers, the curriculum should be oriented to students needs so that the students do not feel under pressured. The fourth is learning media. Special learning media has not fully utilized during the teaching and learning process in school. Although the school used a particular media images for students with autism, the school did not have the media for other types of students with special needs (ABK).

The fifth is financing. The results showed that wages for teachers/coordinator of inclusive education in the school were not adequate. Therefore, the local government should immediately determine and set the policy of waging for the GPK. It needs to be done so that it's not to conflict with employment law, Ketenagakerjaan, Pasal 88, Ayat 4.

The sixth is school committee. The role of the committee is very important to be embodied in implementing of special needs education because society has a variety of resources that are required of schools and society as well as the local government. The Junior High School 10 Banjarmasin has involved the school committee in planning the inclusive education. This is in line with Dadang (2015: 154) who states that the purpose of forming the school committee is the hosts transmit and community initiatives in the operational policy of conducting an education programs in schools.

The seventh is the users satisfaction level. Based on the results of the interview with the parents of the students of Junior High School 10 Banjarmasin, the level of their satisfaction is still low due to the limited service and facilities in the school.

The eighth is Professional Teacher Programs. As the pilot project, teachers of inclusive school should be those who have special educational background and be trained in teaching students with special needs. Such as award program for the dedicated teachers including those teaching loads have exceeded a predetermined threshold. Research results showed that the government failed to develop the program. In fact, such award program is encourage teachers' spirit and enthusiasm to work, and eventually can improve the inclusive education.

The ninth is school rules regarding the standard of education for inclusive management. One indication of the school has a commitment in terms of improving and quality assurance is the existence of a mutual agreement which is contained in the regulations of the school. Then, the school regulations be footing in terms of organizing. Ironically, the schools do not have such regulation currently.

\section{Transaction}

On the aspect of transaction process, the result of the present study is almost same as the results of antecedent. There are some components that had been implemented in accordance with the guidelines, but there is a component which has not been implemented. The components are discussed further in the following description.

First, the teachers of Junior High School 10 Banjarmasin have designed lesson plans for each subject. Based on PP 19 year 2005 Pasal 20, it is stated that: "planning the learning process includes the syllabus and lesson plans which 
contain at least the learning objectives, teaching materials, methods of learning, learning resources, and assessment of the learning.

Second, the teachers of Junior High School 10 Banjarmasin have been trying to develop a learning model that is accessible to all students including those with special needs. However, their efforts are still not effective. Based on the data analysis, the condition has not been in accordance with what is proposed by Efendi (2006: 99) who mentioned that learning in an inclusive school is learning that involves the entire learners including ABK. Therefore, the teacher should create friendly learning atmosphere for all students.

Third, the study showed that students had reports on the assessment of their learning in form of scores in report cards. Unfortunately, the narrative report has not been provided. In fact, such report of assessment in inclusive schools is needed to determine whether student can further to higher class or not based on their achievement of mental prowess which is described narratively.

\section{Learning Outcomes}

On the aspect of outcomes, the results were similar to the results of the previous aspects. The findings showed that there were some components which have been implemented in accordance with the guidelines while others were not. The components included: first, the students had not reached the standard of KKM. It was caused by the unsettled modification assessment for students' learning. According to Mulyono (2005:51), KKM is an achievement of basic competencies of certain criteria to be achieved by student in each subject. Students who have not reached the KKM is considered as not competent. Second is social behavior. Social relationships among students in Junior High School 10 Banjarmasin were very good. The students in the school stated that they appreciated each other.

Third, the graduation of all students of Junior High School 10 Banjarmasin is determined by the national examination (UN) as well as school examination. Permendiknas No. 70 year 2009 has given permission for inclusive schools to test their students' academic competencies by modifying the test in order to meet the students' characteristics. As a result, each inclusive education providers are authorized to develop the students' potential to be individuals with intelligent, skilful, and independent.

Fourth, the inclusive education providers in Banjarmasin have strategy in enable graduate students to further their study to higher level of education. The continuous of education for these students is guaranteed by the state because education is a basic need of every human being without any exception including those with special needs or those disabled children as stated in the Constitution UUD 1945 Pasal 31 Ayat (1).

\section{Conclusion:-}

Based on the discussion of the research findings, the researcher can draw some conclusions as following:

First, the component of the preparation (antecedent) implementation of inclusive education has not been carried out appropriately. It was pointed out that there are still some aspects of the antecedents that have not been conducted in accordance with the standard evaluation criteria such as the identification and assesment of students' learning, teachers' reqruitment, curriculum, facilities and infrastructure, school rules, awards, users' satisfaction level, as well as financing.

Second, the component of process (transaction) in the implementation of inclusive education has not been implemented effectively. In this component, its implementation do not suit with the expectations and standards of the criteria of evaluation among which are the learning plan with Individual Learning Program (PPI) for students with special needs, the curriculum which has not been modified, the use of teaching media and learning resources, the use of methods and learning strategies, and assessment criteria which do not comply with the guidelines of the implementation of inclusive education.

Third, the components of products (outcomes) and the results of implementing inclusive education have not been maximized. There are some components which have not been in accordance with the expectations and standards criteria of evaluation. The outcome which do not meet the standard criteria is student learning outcomes, while the aspects of behavior and graduates are in compliance with the expectations and the criteria of the stakeholders. 


\section{References:-}

1. Arikunto, Suharsimi, Cepi Saefuddin, and Abdul Jabar. (2008). Evaluasi Program Pendidikan Pedoman Teoritis Praktis Bagi Praktisi Pendidikan. Jakarta: Bumi Aksara.

2. Dadang, G. (2015). Pengantar Pendidikan Inklusif. Bandung: Refika Aditama.

3. Daniel L. Stufflebeam and Anthony J. Shinkfield. (1986). Systematic Evaluation: A Self-Instruction Guide to Theory and Practice. Boston: Kluwer Nijhoff Publishing.

4. Djuang Sunanto, dkk. (2009). Implementasi Pendidikan Inklusif di Sekolah Dasar. Bandung: Pusat kajian dan Inovasi Pendidikan - Sekolah Pascasarjana UPI.

5. Direktorat Pendidikan Luar Biasa. (2003). Mengenal Pendidikan Terpadu/Inklusi. Jakarta: Ditjen Dikdasmen.

6. Don E. Gardner. (1977). Five Evaluation Frameworks: Impliction for Decision Making in Higher Education. The Journal of Higher Education, Vol. 48, 5.

7. Efendi, M. (2006). Pengantar Psikopedagogik Anak Berkelainan. Jakarta: PT. Bumi Aksara.

8. Farida Yusuf Tayibnapis. (2008). Evaluasi Program dan Instrumen Evaluasi untuk Program Pendidikan dan Penelitian. Jakarta: Rineka Cipta.

9. Haryono and Ahmad Syaifudin. (2015). Evaluasi Pendidikan Inklusif bagi Anak Berkebutuhan Khusus (ABK) di Provinsi Jawa Tengah Semarang: Jurnal Penelitian Pendidikan, Vol. 32, 2.

10. Kemendikbud. (2003). Undang Undang Republik Indonesia Nomor 20 tahun 2003 tentang Sistem Pendidikan Nasional.

11. Permendiknas. (2009). Peraturan Kemendtrian Pendidikan Nasional Nomor 70 tahun 2009 tentang Pedoman Pelaksanaan Pendidikan Inklusif.

12. Miles, Mattew B. and A. Michael Huberman. (1992). Analisis Data Kualitatif Buku Sumber tentang MetodeMetode Baru. Jakarta: UI Press

13. Mulyono Abdulrahman. (2005). Landasan Pendidikan Inklusif Dan Implikasinya Dalam Penyelenggaraan Pendidikan Inklusif. Bandung: Rosada.

14. Patton, Michel Quinn. (n.d). Metode Evaluasi Kualitatif, terjemahan Budi Puspo Priyadi. Yogyakarta: Pustaka Pelajar.

15. Nd. (2007). Pedoman Khusus Penyelenggaraan Pendidikan Inklusif, Manajemen Sekolah Penyelenggara Pendidikan Inklusif. Jakarta: Direktorat Pembinaan Sekolah Luar Biasa.

16. Pratiwi, C.J. (2015). Sekolah Inklusi Untuk Anak Berkebutuhan Khusus: Tanggapan Terhadap Tantangan Kedepannya. Proseeding UNS.

17. Rahim and Mansur. (2013). Sikap Kepala Sekolah dan Guru Terhadap Pendidikan Inklusif di Kota Banjarmasin. Laporan Penelitian, Lembaga Penelitian, Universitas Lambung Mangkurat Banjarmasin.

18. Robert O. Brinkerhoff, et al. (1986). Program Evaluation: A Practitioner's Guide for Trainers and Educators Boston: Kluwer Nijboff Publishing.

19. Stake, R.E. (1983). "Program Evaluation, Particulary Responsive Evaluation". In George F. Madaus, Michele S. Scriven and Daniel L Stufflebeam (eds), Evaluation Models. Massachusets: Kluwer Academic Publisher.

20. Sukinah. (2010). Manajemen Strategik Implementasi Pendidikan Inklusif. Jurnal Pendidikan Khusus, Vol. 7, 2 , Spring.

21. Tayibnapis and Farida Yusuf. (2008). Evaluasi Program dan lnstrumen Evaluasi untuk Program Pendidikan dan Penelitian. Jakarta: Rineka Cipta.

22. Ummah, U. Manajemen. (2010). Penyelenggaraan Pendidikan Inklusif (Studi Kasus Terhadap Sebuah SD Penyelenggara Pendidikan Inklusif di Kota Bandung dan Sidoarjo). Jurnal Pendidikan Inklusif, Vol. 2, 4, Spring.

23. UNESCO. (1994). Pernyataan Salamanca dan Kerangka Aksi dalam Pendidikan Kebutuhan Khusus. Jakarta: UNESCO Office. 